$\xi=$ 監

\title{
Geochemical assessment of heavy metal pollution of river basin in Nigeria using stream sediment
}

\author{
Oluwafunso Oladipo Awosusi ${ }^{1}$, Adeshina Luqman Adisa ${ }^{1 *}$ \\ ${ }^{1}$ Department of Applied Geology, Federal University of Technology, Akure, Nigeria \\ *Corresponding author E-mail: aladisa@futa.edu.ng
}

\begin{abstract}
Heavy metal pollution has been a source of health problems in humans. These metals are persistent, toxic, non-degradable and often take a long time to be eliminated from the body. This study is, therefore, designed to assess heavy metal pollution of River Basin in Nigeria. Seventy stream sediment samples were systematically collected from an area, approximately $400 \mathrm{~km}^{2}$, latitude $7^{\mathrm{O}} 00^{\prime}$ and $7^{\mathrm{O}} 15^{\prime} \mathrm{N}$ and longitude $5^{\circ} 11^{\prime}$ and $5^{\circ} 19^{\prime} \mathrm{E}$. The pollution status of the sediments by heavy metals were assessed by Enrichment Factor (EF), Pollution Load Index (PLI) and Geo-accumulation Index (Igeo). The concentrations of the heavy metals were also compared with United States Environmental Protection Agency (USEPA) Sediment quality guidelines (SQG). The samples were dried in the laboratory, disaggregated, sieved to minus 80 ( $<177$ microns) mesh size using nylon sieve. The sieved samples were, then, digested and the concentrations of As, Co, $\mathrm{Fe}, \mathrm{Mn}, \mathrm{Ni}, \mathrm{Pb}, \mathrm{V}$ and $\mathrm{Zn}$ were determined by Wavelength Dispersive X-ray Fluorescence Spectrometry (WD-XRFS). Results revealed that the mean concentrations of the heavy metals are in the order $\mathrm{V}>\mathrm{Zn}>\mathrm{Pb}>\mathrm{As}>\mathrm{Ni}>\mathrm{Co}>\mathrm{Fe}>\mathrm{Mn}$. Furthermore, the mean concentration of lead exceeded both the average world shale and the USEPA SQG values. However, the mean concentration of cobalt, nickel, manganese and zinc were lower than the average world shale values for these elements. The Enrichment Factor (EF) revealed that cobalt was moderately enriched while arsenic and lead were significantly enriched in the sediments. On the basis of the geoaccumulation index, the stream sediments were largely uncontaminated except at some sites that were moderately to strongly contaminated by $\mathrm{As}$ and $\mathrm{Pb}$.
\end{abstract}

Keywords: Enrichment Factor; Heavy Metals; Pollution Load Index; Stream Sediment; XRF.

\section{Introduction}

Trace elements, often referred to as Potentially toxic elements, heavy elements or heavy metals, are those elements in rocks whose concentration are less than 0.1\% (Rollinson 1993). Heavy elements have always attracted the attention of researchers. This is because, the pollution of geological materials such as water, soil, stream sediments etc., by these heavy metals have become the leading cause of health problems in humans. These metals are persistent, toxic and non-degradable. They often take a long time to be eliminated from the body. Furthermore, they are one of the most common pollutants of the aquatic environment.

The trace metal content of an aquatic system is controlled by a variety of factors. Some of these factors are, geology, chemical reactivity, mineralogy, hydrology, vegetation, land use pattern and biological activity (Albanese et al. 2013). In order to protect human and the ecosystem, it is imperative that the level of pollution of water and biota by heavy metals be monitored. This monitoring is done by analyzing surface water, soil, suspended materials or stream sediments (Singh et al. 1997).

Of these, stream sediment is the most preferred because it acts as sink for aquatic pollutants, it also has a long residence time and the heavy metal contents are generally above the detection limit (Forstner \& Wittman 1983, Bertin \& Bourg 1995, Albanese et al. 2013).

In order to assess the pollution status of any aquatic system, scientists have employed a number of methods (Nude et al. 2011). These methods include, multivariate statistical methods, enrichment factor, geo-accumulation index, pollution load index, contamination factor etc. This research assesses the pollution of the drainage systems, in the study area, by As, $\mathrm{Co}, \mathrm{Fe}, \mathrm{Ni}, \mathrm{Pb}, \mathrm{Mn}, \mathrm{V}$ and $\mathrm{Zn}$. The objectives are to: (i) assess the trace element contents of the sediments; (ii) compare the level of trace metal contents with the geochemical background values for stream sediment; (iii) establish relationship among the analyzed trace elements; and (iv) assess the pollution status of the drainage system in the study area.

\subsection{Description of the study area}

The study area, latitudes $7^{\circ} 00^{\prime}$ and $7^{\circ} 15^{\prime} \mathrm{N}$ and longitude $5^{\circ} 11^{\prime}$ and $5^{\circ} 19^{\prime} \mathrm{E}$, lies south of Akure (Fig. 1). It covers an area approximately $400 \mathrm{~km}^{2}$. The study area has characteristic fairly low relief with a subtle undulating topography. The northern part of the area, underlain by migmatite, has a gentler topography while the southeastern part, underlain by granite gneiss, is more rugged. The highest point in the area is situated in the south eastern part, about $650 \mathrm{~m}$ above sea level, while the lowest point, about $218 \mathrm{~m}$ above sea level, lies within River Ofosu in the southernmost part of the study area.

The area is well drained by a network of rivers, the two major ones being Iyisin and Ofosu Rivers. River Ofosu drains the western part while River Iyinsin drains the eastern part. However, the two rivers meet at the southern part to form a confluence at Ofosu - Labunwa 
village. Almost all the rivers and streams are seasonal except Ofosu and Iyinsin. The drainage system form a noticeable trellis drainage pattern and they appear to be structurally controlled (Fig. 1). The area is characterized by two climatic seasons, wet and dry seasons. The duration of the wet season is from April to October and it is marked by heavy rainfall, while the dry season, a period of low or no rainfall, spans between November and March.

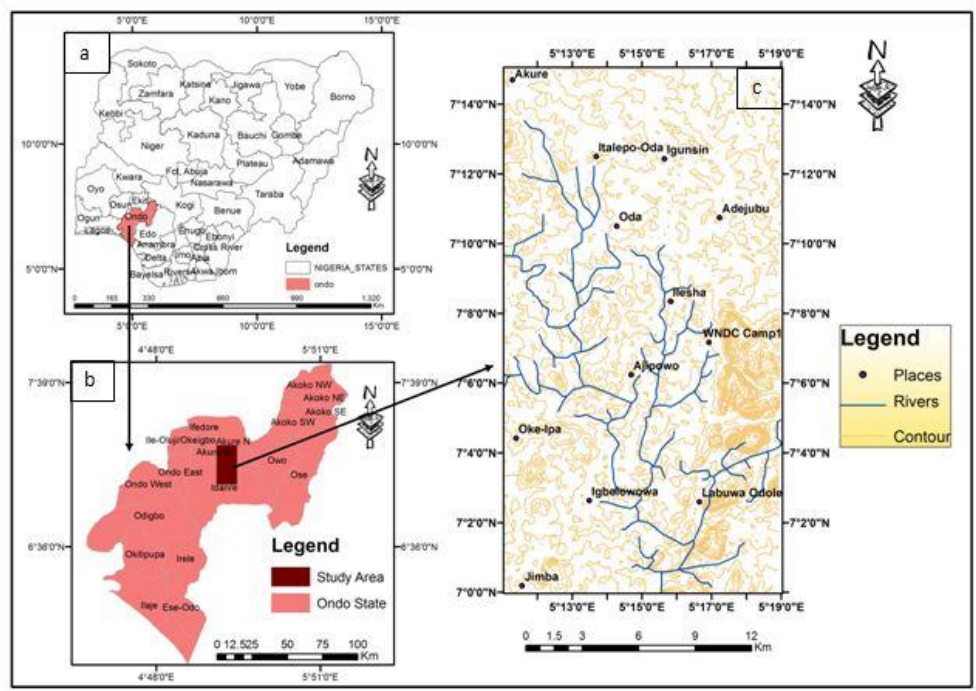

Fig. 1: A) Map of Nigeria Showing Ondo State; B) Administrative Map of Ondo State (Published by the Office of the Surveyor-General of the State, 1998) Showing the Study Area; and C) Map Showing the Drainage Systems in the Study Area.

The area lies within the Basement Complex of Nigeria. It is Precambrian in age, forms part of the West African mobile belt and lies between the West African and the Congo craton and south of Tuareg shield (Black 1980). Adekoya (1991) and Adekoya et al., (2003) have subdivided the Basement Complex rocks of Nigeria on tectono-stratigraphic basis into four major rock groups, namely:

i) The Migmitite Gneiss Quartzite complex;

ii) The supracrustal Schist Belt;

iii) The Older Granite and associated granitiods; and

iv) The minor felsic and mafic intrusives.

Rivers Iyinsin and Ofosu drainage systems drain an area underlain by the basement complex rocks. The rock units are as shown in the geological map of the area (Fig. 2). The oldest rock unit, migmatite, was intruded by granite gneiss, undifferentiated Older granites with porphyroblastic gneiss, coarse porphyritic biotite and biotite-hornblende granites, fine-grained biotite granite and pegmatite (Fig. 2). This oldest unit is extensive as it covers about $65 \%$ of the area and spans from north to south. The coarse porphyritic biotite and biotite-hornblende granite occur as inselbergs and extends as far as Idanre area forming the popular Idanre Hills. Pegmatite is highly weathered, trends in the north-south direction and it is the youngest unit in the area (Awosusi \& Adisa 2019).

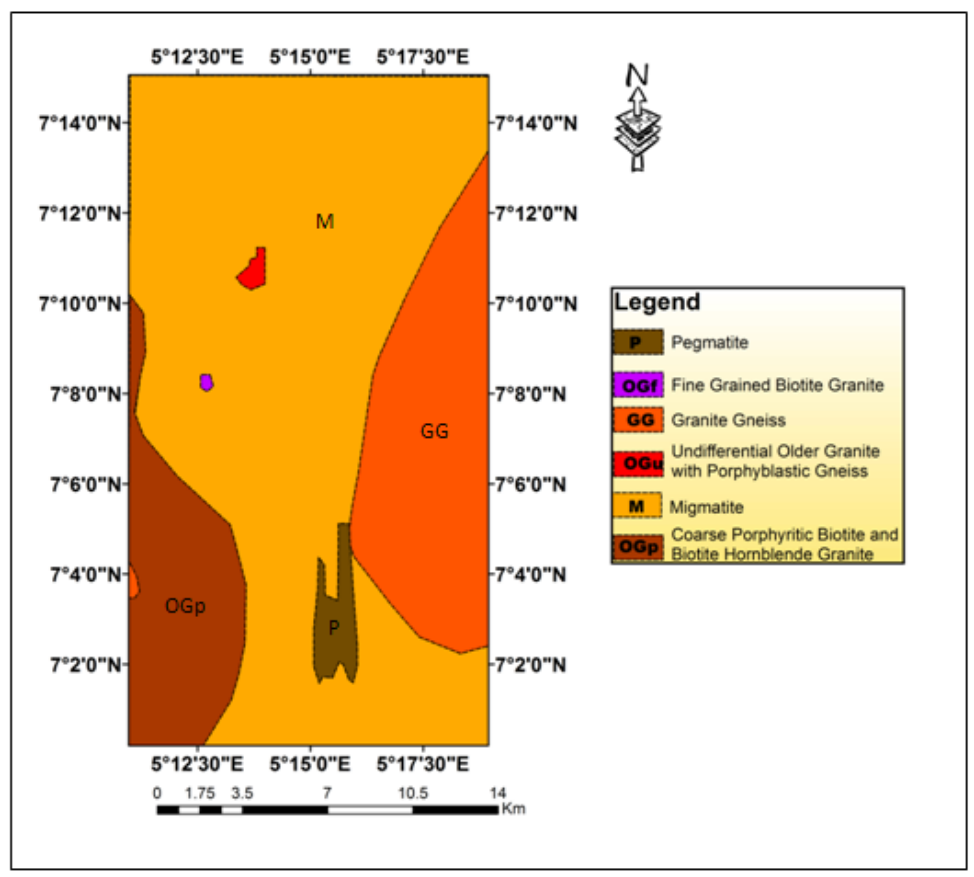

Fig. 2: Geological Map of the Study Area (Akure - Oda - Idanre Area) (Adapted From Nigerian Geological Survey Agency, 2006). 


\section{Materials and methods}

\subsection{Data acquisition}

The methodology involved two stages. Stage one which was the fieldwork phase, was carried out between February and March 2008. It involved the systematic stream sediment sampling of Rivers Iyinsin and Ofosu and their tributaries. These rivers are in Oda and Idanre areas on 1: 50,000 topographic maps, sheet number 264 (Akure S.W and Akure S. E.). During this phase, a total of eighty - seven stream sediment samples were collected at a depth of $15 \mathrm{~cm}$ and interval of 1 to $1.5 \mathrm{~km}$ along the river channels (Fig. 3). The samples were collected as near the centre of the river channels as possible. It was also ensured that samples were collected at the confluence of two or more streams or rivers. In order to avoid contamination, the collection was done with a plastic scoop and afterward put in a pre-labeled sample bag. At each sample location, observations such as the direction of flow of the river, the lithology as well as the coordinates were made and recorded. The coordinates of the sampling locations were taken using a Global Position System (GPS).

\subsection{Geochemical analysis}

The second stage of the research methodology was the laboratory stage. This stage involved sample preparation and analysis. In the laboratory, the collected samples were prepared for geochemical analysis by first air-drying them for two weeks at room temperature. The dried samples were then disaggregated using porcelain mortar and pestles and later sieved to minus 80 ( $<177$ microns $)$ mesh size using nylon sieve. Thereafter, $200 \mathrm{~g}$ of each of the selected seventy sieved stream sediment samples were then sent to the Earth Sciences Department, University of Western Cape, Bellvile, South Africa. The concentrations of As, $\mathrm{Co}, \mathrm{Fe}, \mathrm{Mn}, \mathrm{Ni}, \mathrm{Pb}, \mathrm{V}$ and $\mathrm{Zn}$ present in the samples were determined by Wavelength Dispersive X-ray Fluorescence Spectrometry (WD-XRFS) on pressed powder pellets using the Phillips PW1480 automated spectrometer equipped with a Rhodium anode. Analytical precision for both major and trace elements were better than $8 \%$. Both accuracy and precision were reasonable and satisfactory.

\subsection{Heavy metal pollution of the drainage system}

\subsubsection{Statistical analysis of data}

In order to assess the nature of the geochemical data, univariate statistical analyses such as mean, maximum, minimum, 1st quartile, median, 3rd quartile, standard deviation, coefficient of variation, skewness and kurtosis were computed for the analyzed elements. This univariate analysis revealed the geochemical distribution of the elements. The data were also compared with US Environmental Protection Agency (USEPA) sediment quality guidelines (SQG) as well as Average shale values. Pearson linear correlation matrix was also generated. This was done in order to have an insight into the inter-element relationships.

The stream sediment geochemical data was presented in form of box and whisker plots. Enrichment factor (EF), Geo-accumulation index (Igeo) and Pollution Load Index (PLI) were presented in form of tables, box plots and charts. All these statistical computations were done using Excel and Statistical Package for Social Sciences (SPSS) software version 16.0.

\subsubsection{Determination of enrichment factor (EF)}

In this research work, the pollution status of the study area was assessed by computing the Enrichment Factor (EF), Pollution load index (PLI), as well as the Geo-accumulation Index (Igeo). The Enrichment Factor (EF), defined by Hernandez et al. (2003) as "the relative abundance of a chemical element in soil (or sediment) compared to the bedrock".

EF was computed by comparing the concentration of the element and the reference element in the sample to the Clark or average shale values, using the formula (Reimann \& De Caritat 2005, Galuszka \& Migaszewski 2011).

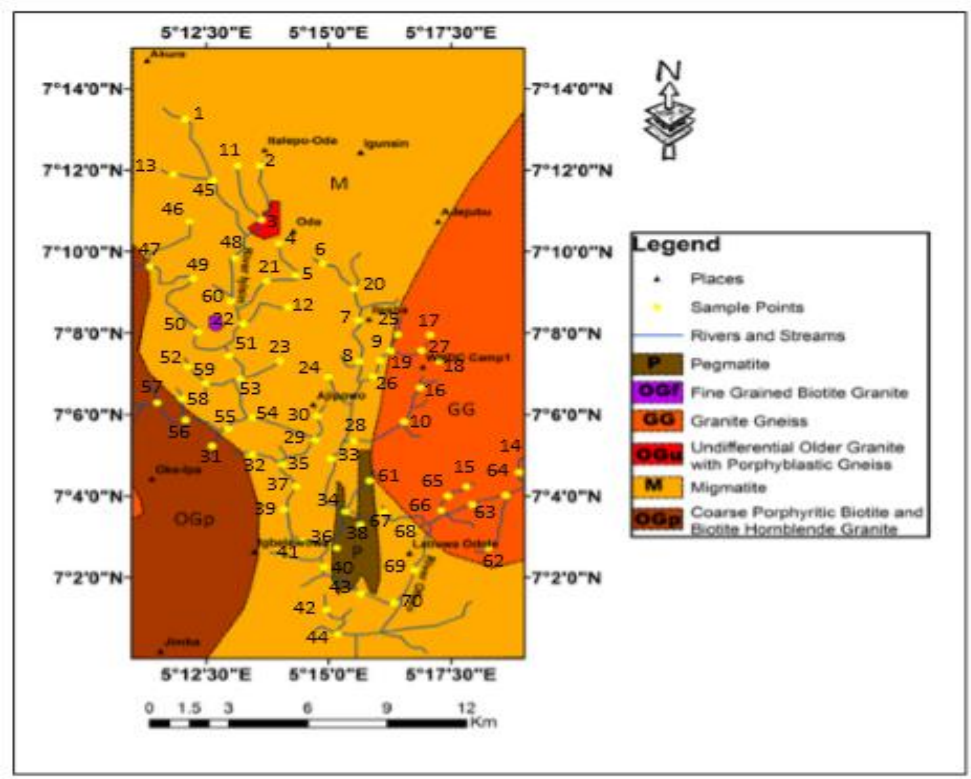

Fig. 3: Geological Map of Akure-Oda-Idanre Area Showing the Sample Locations (Adapted from Nigerian Geological Survey Agency, 2006).

$\mathrm{EF}_{\mathrm{m}}=\left(\frac{C_{n}}{F_{\theta}}\right)$ sample $/\left(\frac{C_{n}}{F_{e}}\right)$ background 
Where:

$\mathrm{C}_{\mathrm{n}}=$ Concentration of trace element in the sample;

$\mathrm{Fe}_{\text {sample }}=$ Concentration of the reference element in the sample;

$\mathrm{C}_{\mathrm{n} \text { (background) }}=$ Clarke value or average shale value of the element; and

$\mathrm{Fe}$ (background) $=$ Clarke value or average shale value of the reference element.

The background value adopted is that of average shale (Turekian \& Wedephol 1961). According to Galuszka \& Migaszewski (2011), reference elements often used in the computation of EF are Si, Al, Fe, Sc, Zr or Ti (Reimann \& De Caritat 2005). These are elements whose concentrations are so abundant in the earth's crust that anthropogenic influences do not change them substantially. Different researchers have used different reference elements in the computation of EF values. For example, Sakan et al. (2014) used aluminum while Nude et al. (2011) used $\mathrm{Ca}$ as reference material.

In this study, Fe was adopted as the normalizing element in determining the EF values. Fe was adopted because of its high mobility in an oxidizing surface environment, low occurrence variability and its occurrence in the environment in trace amounts (Loska et al. 2003, Nyangababo et al. 2005, Kamaruzzamal et al. 2008, Chakravarty \& Patgiri, 2009).

\subsubsection{Determination of pollution load index (PLI)}

Pollution load Index (PLI) is another factor often used in environmental geochemistry to assess the pollution status of sediment. Prior to the computation of PLI, the Contamination factor was first obtained by dividing the concentration of each metal in the sediments by the background value (Rabee et al. 2011):

Contamination Factor $(\mathrm{CF})=$ Metal concentration in sediments/ background values of metal

I.e. $\mathrm{CF}=\mathrm{C}_{\text {metal }} / \mathrm{C}$ background

Thereafter, the PLI was computed by obtaining the n-root from the n-CFs that were obtained for all the metals (Soares et al. 1999). PLI was computed as follows:

$\mathrm{PLI}=(\mathrm{CF} 1 * \mathrm{CF} 2 * \mathrm{CF} 3 \ldots * \mathrm{CFn})^{1 / n}$

Where $\mathrm{n}$ is the number of elements determined.

The values obtained for PLI were later presented in the form of table and chart using Microsoft Excel. Galuszka \& Migaszewski (2011) equated the background value of metal to the "pre-industrial concentration or the average shale" (Loska et al. 2003) or the average world shale value or Clarke value (Tomlinson et al. 1980).

\subsubsection{Determination of geo-accumulation index (Igeo)}

The geo-accumulation index (Igeo) is another factor used to evaluate the degree of trace metal contamination in geological sample e.g. soil, stream sediment etc. This factor is computed by comparing the current and pre-industrial concentrations (Muller 1981).

$\mathrm{I}_{\mathrm{geo}}=\log _{2}\left(\mathrm{Cn} / 1.5 \mathrm{~B}_{\mathrm{n}}\right)$

Where:

$\mathrm{C}_{\mathrm{n}}=$ the measured concentration of analyzed metal (n) in the geological sample (i.e. sediment);

$\mathrm{B}_{\mathrm{n}}=$ the geochemical background concentration of the metal (n); and 1.5 is the background matrix correction factor due to the lithogenic effects.

\section{Results and discussion}

\subsection{Heavy metal distribution}

The descriptive statistics for the concentrations of the trace elements from the stream sediments of the study area are summarized in Table 1 and Fig. 4. The results revealed that As, Co, Mn, Ni and V have a high coefficient of variation (CV). This could be as a result of the heterogeneous spatial distribution of these elements in the stream sediments (Table 1). This distribution pattern is confirmed by the median concentrations being less than the mean for these elements. Furthermore, the high CV values exhibited by As, Co, Mn, Ni and V may be attributed to the high concentrations of the trace elements in the sediments. However, $\mathrm{Fe}$ and $\mathrm{Pb}$ exhibited low $\mathrm{CV}$ values suggesting homogeneous spatial distribution of these elements. This is evident in the both the median and mean concentrations of these elements having similar values.

Co concentration values ranged from $4 \mathrm{ppm}$ to $49 \mathrm{ppm}$ (Table 1 and Fig. 4) with the mean concentration of $17.69 \mathrm{ppm}$. This value is lower than the "average world shale" value. Therefore, the river sediments were unpolluted by Co. V concentration values ranged from 3.5 ppm to $578 \mathrm{ppm}$, with a mean concentration of $126.83 \mathrm{ppm}$. This mean value is lower than the corresponding "average world shale"(Table 2). $\mathrm{Zn}$ with a mean concentration of $76.9 \mathrm{ppm}$, ranged from $36 \mathrm{ppm}$ to $211 \mathrm{ppm}$. When the mean concentration is compared with the average world shale and USEPA Sediment quality guideline values for $\mathrm{Zn}$, the mean concentration is lower.

Table 1: Summary Statistics of Trace Element Concentrations in Stream Sediment ( $<177$ um) Samples

\begin{tabular}{|c|c|c|c|c|c|c|c|c|c|c|c|}
\hline & Minimum & Maximum & Median & Mean & 1st Quartile & 3rd Qurt. & SD & Variance & $\mathrm{CV}$ & Skewness & Kurtosis \\
\hline As & 1 & 100 & 23.00 & 29.27 & 16.5 & 39.5 & 20.18 & 407.22 & 2018.00 & 1.6 & 3.15 \\
\hline $\mathrm{Co}$ & 4 & 49 & 15.52 & 17.69 & 10 & 25 & 10.19 & 103.8 & 254.75 & 0.88 & 0.37 \\
\hline $\mathrm{Fe}$ & 1.67 & 20.26 & 8.09 & 8.15 & 6.25 & 9.6 & 3.16 & 10.01 & 189.22 & 0.83 & 2.18 \\
\hline Mn & 0.03 & 0.29 & 0.09 & 0.11 & 0.06 & 0.153 & 0.059 & 0.004 & 196.67 & 0.84 & 0.15 \\
\hline $\mathrm{Ni}$ & 1 & 70 & 14.00 & 17.92 & 7.64 & 25.25 & 14.37 & 206.44 & 1437.00 & 1.68 & 3.51 \\
\hline $\mathrm{Pb}$ & 18 & 86 & 56 & 57.23 & 49 & 66.25 & 13.84 & 191.5 & 76.89 & -0.12 & 0.36 \\
\hline V & 3.5 & 578 & 102.5 & 126.83 & 59 & 159.75 & 104.77 & 10976.91 & 2993.43 & 2.02 & 5.25 \\
\hline $\mathrm{Zn}$ & 36 & 211 & 76 & 76.9 & 50.96 & 96.5 & 32.5 & 1054 & 90.28 & 1.31 & 3.79 \\
\hline
\end{tabular}



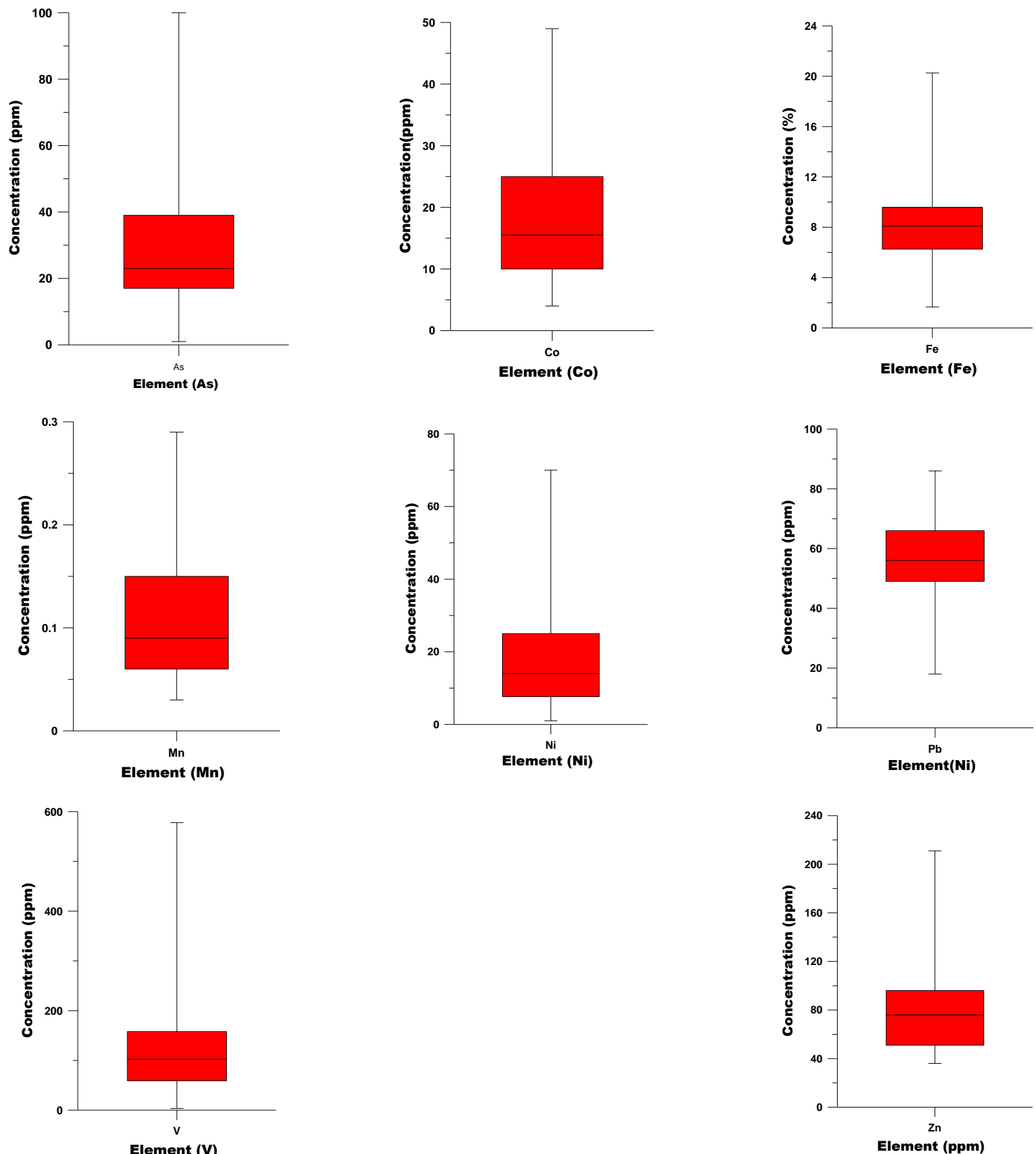

Fig. 4: Box Plot of Trace Element Concentrations in the Stream Sediments from the Study Area.

The mean concentrations for $\mathrm{Ni}$ and $\mathrm{Pb}$ are $1.12 \mathrm{ppm}$ and $1.43 \mathrm{ppm}$ times higher than the corresponding USEPA SQG values for these elements (Table 2). Fe, which ranged from $1.67 \%$ to $20.26 \%$, had a mean 1.72 times higher than the corresponding average world shale values. This value is however less than the corresponding USEPA SQG value for Fe. Furthermore, the mean concentration of Mn in the sediments is lower than both the USEPA and average world shale values. Therefore, on the basis of comparison with the average world shale values. The sediments exihibited background concentration and are unpolluted with respect to $\mathrm{Co}, \mathrm{Mn}, \mathrm{Ni}, \mathrm{V}$ and $\mathrm{Zn}$ while on the basis of USEPA sediment quality guidelines, the sediments are unpolluted by $\mathrm{Zn}, \mathrm{Mn}$ and Fe. These elements, therefore, do not pose any environmental risk.

Table 3 shows the Pearson Correlation coefficient matrix for the heavy elements under consideration. The table indicate both positive and negative correlations with the coefficient " $\mathrm{r}$ " ranging from -0.33 for $\mathrm{Pb} / \mathrm{V}$ to 0.623 for $\mathrm{Pb} / \mathrm{Zn}$. Strong positive correlations exist between $\mathrm{Pb} / \mathrm{Zn}$ while moderate correlations exist between $\mathrm{Fe} / \mathrm{Zn}, \mathrm{Fe} / \mathrm{V}$, and $\mathrm{Mn} / \mathrm{V}$. These positive correlations may indicate a common source for these heavy metals. For example, the positive correlation between Fe and V (i.e. Fe/V) and $\mathrm{Mn}$ and V (i.e. Mn/V) may indicate the scavenging action of hydrous $\mathrm{Fe}$ and $\mathrm{Mn}$ oxides on these heavy elements. Hydrous $\mathrm{Fe}$ and $\mathrm{Mn}$ oxides have the ability to scavenge elements with which they come in contact with (Levinson 1974). Anthropogenic activities could probably be a source of the strong positive correlations. $\mathrm{Pb}$ and $\mathrm{Zn}$ are components of fertilizers which could have been applied to some of the cultivated fields in the area.

\subsection{Assessment of stream sediment pollution}

\subsubsection{Enrichment factor}

Presented in Fig. 5 are values of the enrichment factor (EF), for the analyzed geochemical elements in the stream sediment of the study area, in form of box plots. Zhang and Liu (2002) and Sutherland (2000) have given different classification for EF values. While Sutherland 
(2000) classified EF values into six categories (Table 4), Zhang and Liu (2002) classified it into two. In this research work, we adopted the classification of Sutherland (2000) in interpreting the EF values of the analyzed elements.

Table 2: Comparison of Mean Concentrations of Elements with USEPA and Average Shale Values

\begin{tabular}{llll}
\hline & Mean & $*$ USEPA & **Average Shale \\
\hline $\mathrm{As}$ & 29.27 & - & - \\
$\mathrm{Co}$ & 17.69 & - & 19 \\
$\mathrm{Fe}$ & 8.15 & 30 & 4.7 \\
$\mathrm{Mn}$ & 0.11 & 30 & 850 \\
$\mathrm{Ni}$ & 17.92 & 16 & 68 \\
$\mathrm{~Pb}$ & 57.23 & 40 & 20 \\
$\mathrm{~V}$ & 126.83 & - & 130 \\
$\mathrm{Zn}$ & 76.9 & 110 & 95 \\
\hline
\end{tabular}

*US Environmental Protection Agency Sediment Quality Guidelines.

$* *$ World geochemical background value in average shale (Turekian \& Wedepohl 1961).

Table 3: Pearson Correlation Matrix for Stream Sediment Data from the Study Area

\begin{tabular}{llllllll}
\hline & $\mathrm{As}$ & $\mathrm{Co}$ & $\mathrm{Mn}$ & $\mathrm{Ni}$ & $\mathrm{Pb}$ & $\mathrm{Fe}$ & $\mathrm{Z}$ \\
$\mathrm{As}$ & 1.000 & & & & & \\
$\mathrm{Co}$ & 0.283 & 1.000 & & & & \\
$\mathrm{Mn}$ & 0.260 & 0.253 & 1.000 & & & \\
$\mathrm{Ni}$ & -0.260 & 0.164 & -0.032 & 1.000 & & \\
$\mathrm{~Pb}$ & -0.189 & 0.081 & -0.139 & 0.263 & 1.000 & 1.000 & \\
$\mathrm{Fe}$ & 0.371 & 0.226 & 0.371 & 0.124 & 0.375 & 0.417 \\
$\mathrm{~V}$ & 0.213 & 0.007 & 0.403 & 0.101 & -0.33 & 0.463 \\
$\mathrm{Zn}$ & -0.219 & 0.117 & 0.225 & 0.382 & 0.623 & 0.056 \\
\hline
\end{tabular}

Correlation are significant at $\mathrm{p}<0.05$.

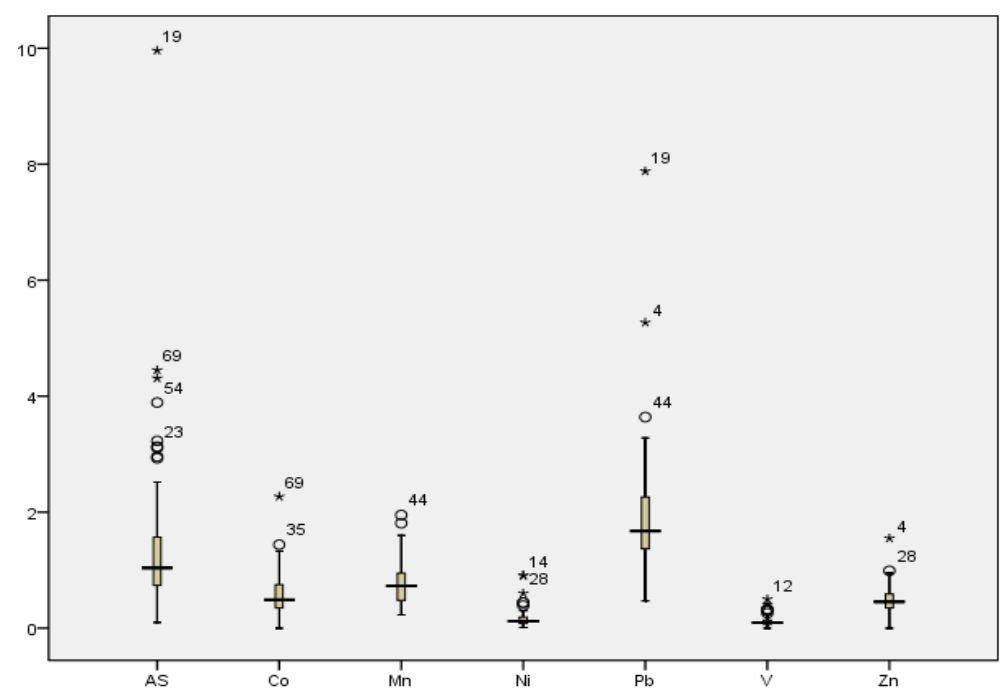

Fig. 5: Box Plots of Enrichment Factors (EF) of the Trace Elements in the Stream Sediments.

Table 4: Classification of Enrichment Factor (EF), Pollution Load Index (PLI) and Geo-accumulation Index (IGEO)

\begin{tabular}{lll}
\hline Index & Value & Degree of Contamination \\
\hline EF & $<1$ & Background concentration \\
& $1-2$ & Depletion to minimal enrichment \\
& $2-5$ & Moderate enrichment \\
& $5-20$ & Significant enrichment \\
& $20-40$ & Very high enrichment \\
& $>40$ & Extremely high enrichment \\
PLI & $<1$ & Polluted \\
& $>1$ & No Pollution \\
& $<0$ & \\
Igeo & $0-1$ & Uncontaminated \\
& $1-2$ & Uncontaminated to moderately contaminated \\
& $2-3$ & Moderately contaminated \\
& $3-4$ & Moderately to strongly contaminated \\
& $4-5$ & Strongly contaminated \\
& $>5$ & Strongly to extremely contaminated \\
\hline
\end{tabular}

The EF values of the heavy metals ranged as follows: As $(0.72-9.96)$; Co $(0.09-2.27)$; Mn $(0.23-1.95)$; Ni $(0.01-0.91)$; Pb $(0.47-$ 7.88); V (0.02 - 2.33); and Zn (0.15 - 1.55) (Fig. 5). The EF values for Co, Mn, Ni, V and Zn are less than 2. The percentage of sample sites where the EF values are < 1 are as follows: As (44.3\% of the sampling sites), Co (87.1\%); Mn (77.1\%); Ni (100 \%); Pb (4.3\%); V $(100 \%)$ and $\mathrm{Zn}(98.6 \%)$. These elements, therefore, fall within the range of background concentration at the sampling sites (Fig. 6). Those that fall in the range of depletion to minimal enrichment $(1<\mathrm{EF}<2)$ are: As $(41.4 \%) ; \mathrm{Co}(11.4 \%) ; \mathrm{Mn}(22.9 \%) ; \mathrm{Ni}(0 \%) ; \mathrm{Pb}(64.3 \%) ; \mathrm{V}$ $(0 \%)$ and $\mathrm{Zn}(1.4 \%)$. This implies that, these elements pose no risk of contamination or pollution in the stream sediment and associated medium (water). Those that fall within the range of moderate enrichment are: $12.9 \%$ of the sampling sites (As); $1.4 \%$ of the sampling 
sites for $\mathrm{Co}$ and $28.6 \%$ of the sampling sites for $\mathrm{Pb}$, while $1.4 \%$ and $2.9 \%$ of the sampling sites have significant enrichments for As and $\mathrm{Pb}$ respectively.

Therefore, on the basis of EF, only As (at site IY 69) and Pb (at sites IY 04 and IY 19) are significantly enriched with respect to these elements, while $\mathrm{As}, \mathrm{Co}, \mathrm{Pb}$ show moderate enrichment in the sediments.

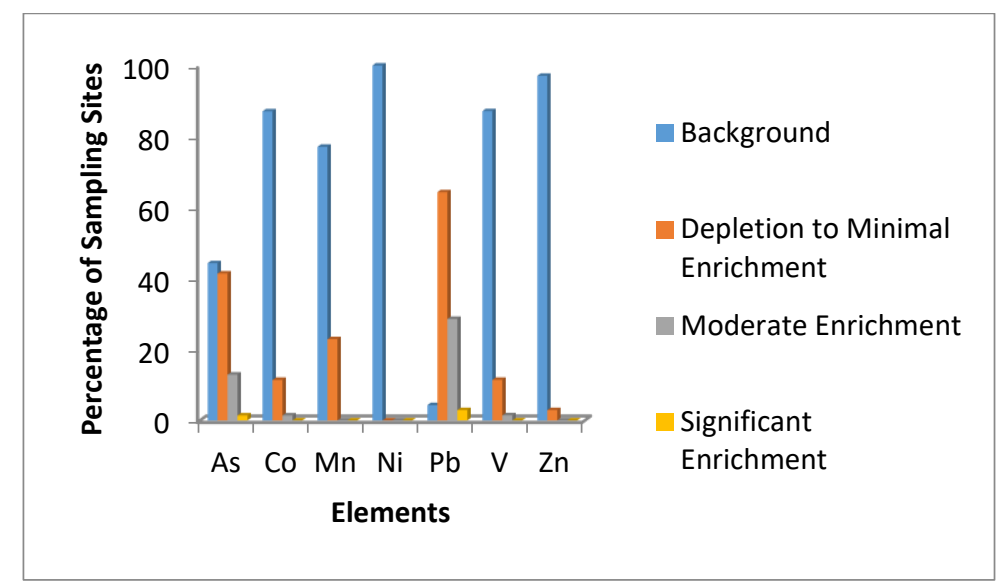

Fig. 6: Percentage Enrichment of Heavy Metals in Stream Sediments from the Study Area.

\subsubsection{Pollution load index (PLI)}

Adebowale et al. (2009) explained the PLI as an index which serve as a quick tool for comparing the pollution status of the different sampling sites. PLI > 1 is an indication of pollution whereas PLI < 1 is unpolluted (Chakravarty \& Patgiri, 2009, Seshan et al. 2010). Figure 7 showed that pollution levels of some of the sites are high (i.e. PLI> 1) while the PLI values in some were low indicating non-pollution (Table 5 and Fig. 7).

\begin{tabular}{|c|c|c|c|}
\hline Sampling sites & PLI & Sampling sites & PLI \\
\hline IY01 & 1.87 & IY36 & 0.97 \\
\hline IY02 & 1.02 & IY37 & 1.00 \\
\hline IY03 & 0.78 & IY38 & 0.78 \\
\hline IY04 & 0.50 & IY39 & 1.73 \\
\hline IY05 & 1.38 & IY40 & 1.17 \\
\hline IY06 & 1.26 & IY41 & 1.23 \\
\hline IY07 & 1.09 & IY42 & 1.39 \\
\hline IY08 & 0.42 & IY43 & 1.00 \\
\hline IY09 & 1.09 & IY44 & 0.50 \\
\hline IY10 & 0.89 & IY45 & 0.53 \\
\hline IY11 & 0.72 & IY46 & 0.87 \\
\hline IY12 & 0.98 & IY47 & 1.12 \\
\hline IY13 & 1.26 & IY48 & 0.93 \\
\hline IY14 & 1.26 & IY49 & 0.70 \\
\hline IY15 & 1.25 & IY50 & 1.06 \\
\hline IY16 & 1.22 & IY51 & 1.26 \\
\hline IY17 & 0.59 & IY52 & 0.50 \\
\hline IY18 & 1.26 & IY53 & 0.58 \\
\hline IY19 & 0.42 & IY54 & 1.27 \\
\hline IY20 & 1.26 & IY55 & 1.01 \\
\hline IY 21 & 1.01 & IY56 & 1.36 \\
\hline IY22 & 0.99 & IY57 & 1.13 \\
\hline IY23 & 0.56 & IY58 & 0.94 \\
\hline IY24 & 1.32 & IY59 & 0.88 \\
\hline IY25 & 0.85 & IY60 & 0.90 \\
\hline IY26 & 1.64 & IY61 & 1.11 \\
\hline IY27 & 1.12 & IY62 & 1.14 \\
\hline IY28 & 0.89 & IY63 & 1.15 \\
\hline IY29 & 0.59 & IY64 & 1.00 \\
\hline IY30 & 0.58 & IY65 & 0.82 \\
\hline IY31 & 1.42 & IY66 & 1.06 \\
\hline IY32 & 1.02 & IY67 & 1.12 \\
\hline IY33 & 1.36 & IY68 & 1.08 \\
\hline IY34 & 1.10 & IY69 & 0.45 \\
\hline IY35 & 0.55 & IY70 & 1.08 \\
\hline
\end{tabular}

\subsubsection{Geo-accumulation Index (Igeo)}

The computed geo-accumulation index (Igeo) values for the stream sediment of the study area are presented in Figure. 8. These values have been interpreted using Muller (1981) Igeo classification (Table 4). 


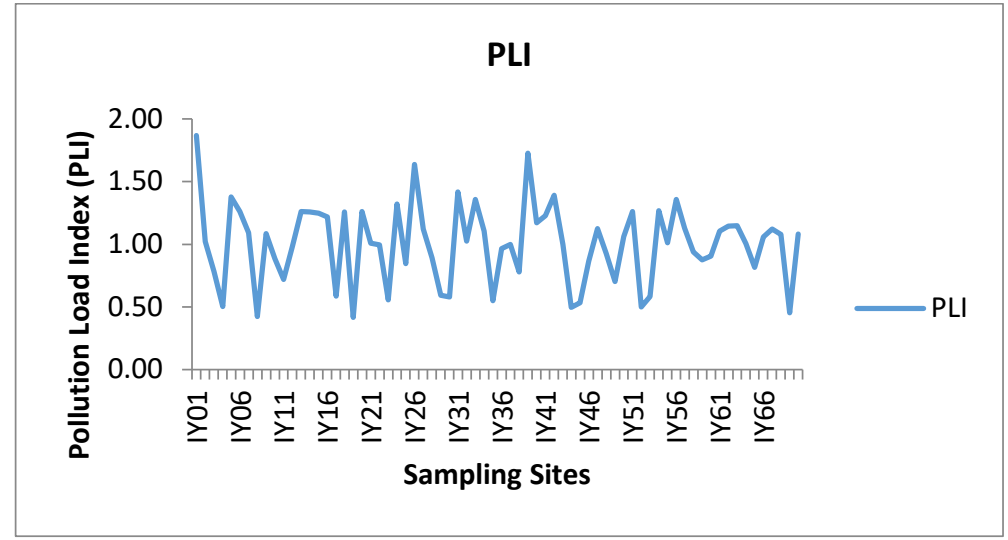

Fig. 7: Pollution Load Index (PLI) Values for Heavy Metals from the Stream Sediment of the Study Area.

The Igeo values for $\mathrm{Mn}, \mathrm{Co}, \mathrm{Fe}$, and $\mathrm{V}$ are less than 1 (i.e. Igeo $<1$ ). The values for these elements, therefore, fall within the range of uncontaminated to moderately contaminated except at Site IY57 which has Igeo of $1.19 \mathrm{ppm}$ for Mn. Other sites such as IY24 and IY39 for Fe and IY12 and IY39 for V had Igeo values that fall within the class of moderately contaminated (Figure 8).

The sediments of Rivers Iyinsin and Ofosu are uncontaminated with respect to $\mathrm{Ni}$ and $\mathrm{Zn}$ as virtually all the Igeo values are less than 0 (i.e. Igeo< 0$)$. However, a critical look at the Igeo values for $\mathrm{As}$ and $\mathrm{Pb}$ revealed that, these two heavy metals had more sites with values ranging between 1 and 2 (i.e. $1<$ Igeo<2) than the other elements. The highest Igeo value is 2.36 at IY54 for As and 1.52 (at IY24 and IY 26) for $\mathrm{Pb}$ which showed that the sediment is moderately to strongly contaminated with respect to these elements (Fig. 8).The sites were high Igeo values were recorded for both $\mathrm{As}$ and $\mathrm{Pb}$ are cultivated areas. Therefore, the source of these elements could probably be from the use of fertilizers and herbicides applied to these areas.

In conclusion, on the basis of geo-accumulation index (Igeo), the stream sediment from the study area are largely uncontaminated, except for some moderate contamination recorded at some sites.
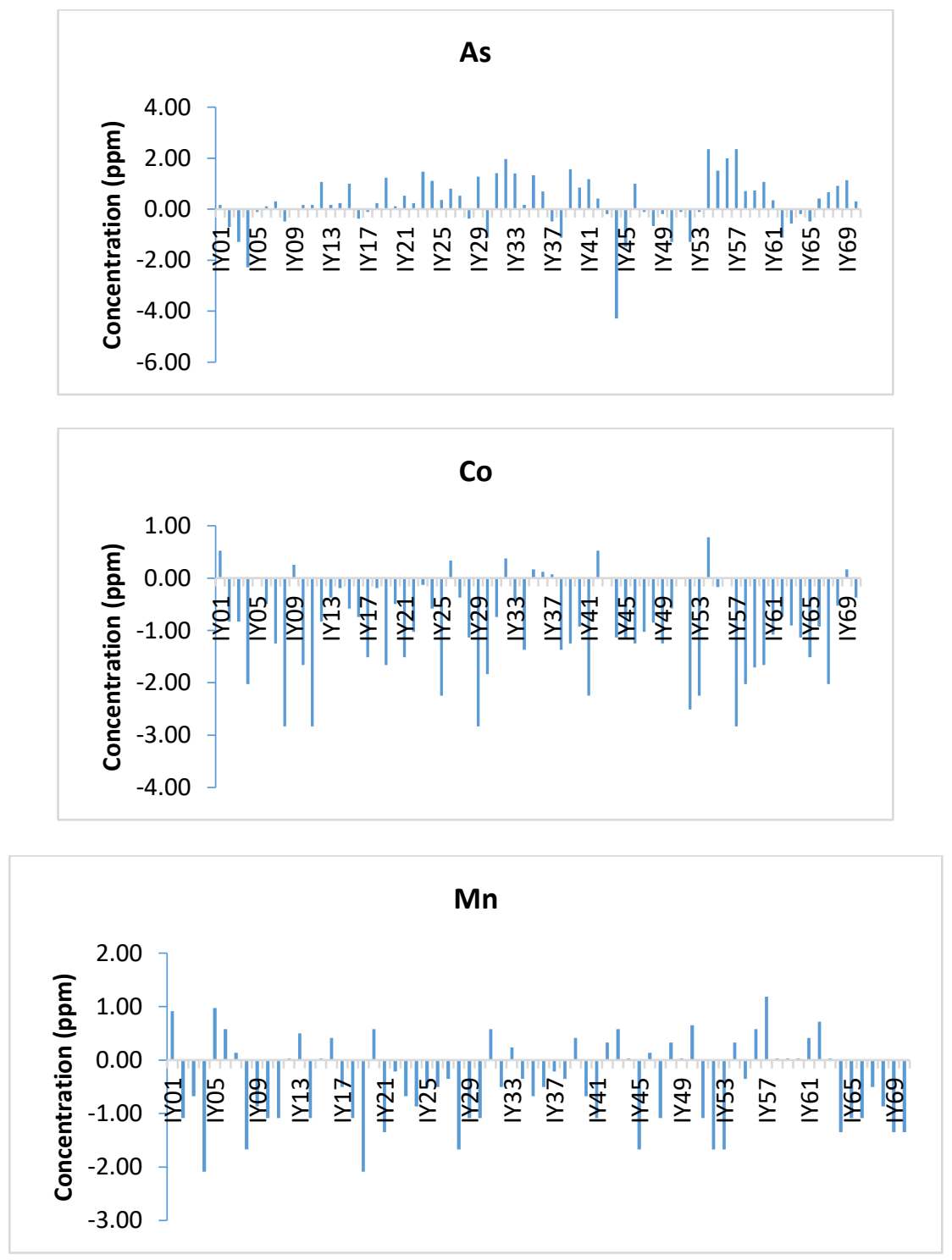


\section{$\mathbf{N i}$}

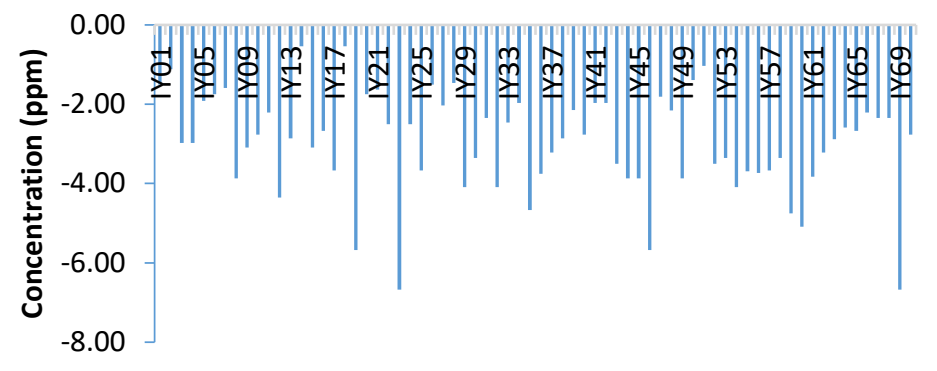

$\mathrm{Pb}$

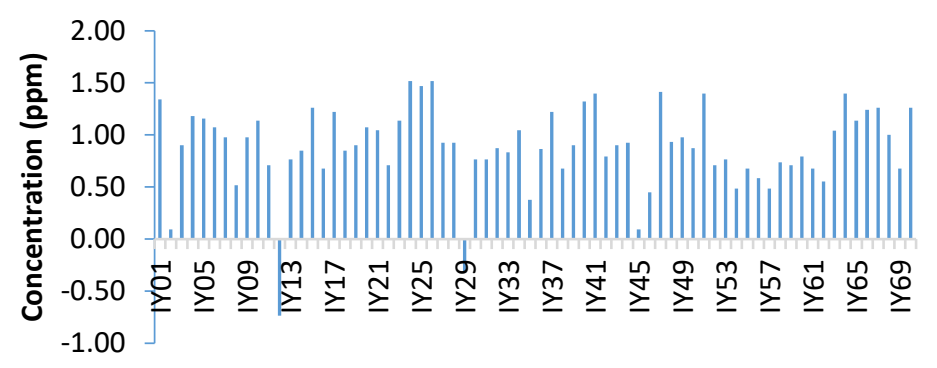

Fe

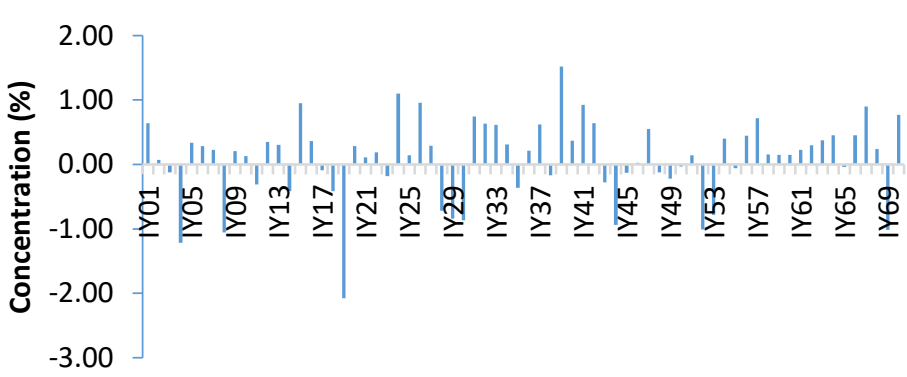

\section{V}

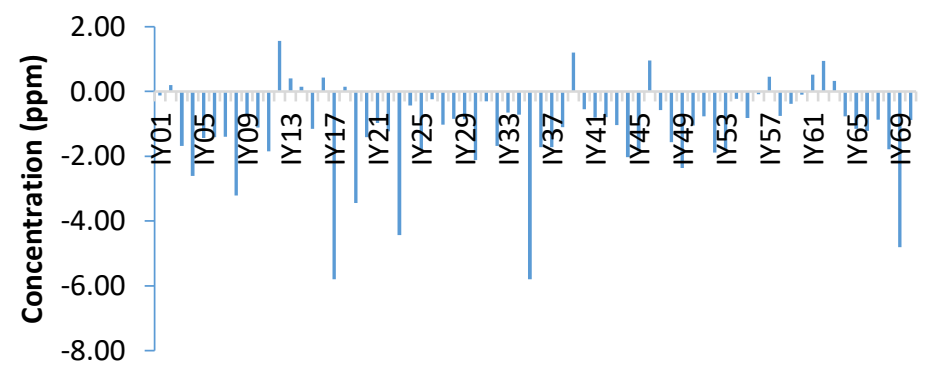

$\mathrm{Zn}$

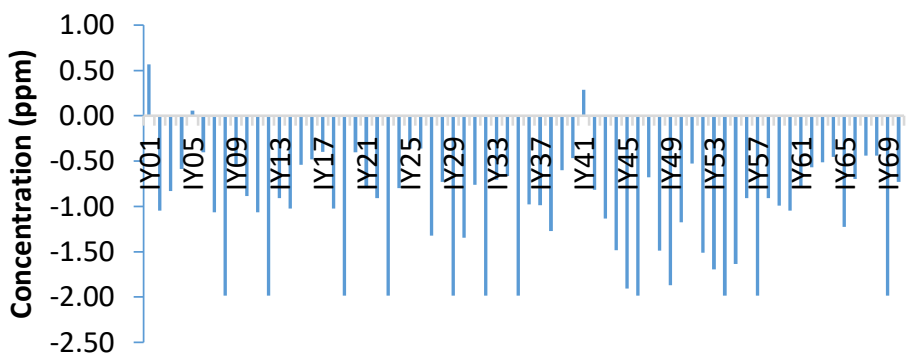

Table 8: Geo-Accumulation Index for the Analyzed Heavy Metals in Stream Sediment from the Study Area. 


\section{Summary and conclusion}

The study is aimed at evaluating the pollution status of heavy metals in the stream sediments of the study area. The study revealed that these heavy metals were widely distributed in the stream sediments. The mean concentrations of the heavy metals are in the order: $\mathrm{V}>\mathrm{Zn}>\mathrm{Pb}>\mathrm{As}>\mathrm{Ni}>\mathrm{Co}>\mathrm{Fe}>\mathrm{Mn}$. With the exception of $\mathrm{Pb}$ and $\mathrm{Ni}$, the mean concentrations of all the other elements are lower than the corresponding values for both the average world shale and the USEPA sediment quality guidelines. Therefore, these elements exhibited background concentrations. $\mathrm{Mn}, \mathrm{V}$ and $\mathrm{Zn}$ showed depletion to minimal enrichment while As, Co (in some few locations) as well as $\mathrm{Pb}$ showed moderate to significant enrichment in the stream sediments. Considering the PLI, this index revealed that most of the sampling sites (59 percent) are polluted. The PLI values of these sites are higher than one.

On the basis of the geo-accumulation index, the stream sediments are largely uncontaminated except some sites that are moderately to strongly contaminated by $\mathrm{As}$ and $\mathrm{Pb}$. The sources of both arsenic and lead are probably anthropogenic. This is because the areas where the high values were recorded for these elements are cultivated fields. These elements could probably have been added to the soil by the application of agrochemicals such as fertilizers and herbicides to these areas.

\section{References}

[1] Adebowale KO, Agunbiade FO \& Olu-owolabi (2009) Trace metal concentration, site variations and partitioning pattern in water and bottom sediments from coastal area: A case study of Ondo Coast, Nigeria. Environmental Research Journal, 3(2), 46-59.

[2] Adekoya JA (1991) The geology of the banded iron - formation in the Precambrian Basement Complex of northern Nigeria. Unpubl. Ph.D. Thesis. University of Ibadan, Nigeria. 395pp.

[3] Adekoya JA, Kehinde-Phillips OO \& Odukoya AM (2003) Geological distribution of mineral resources in southwestern Nigeria. In: Prospects for investment in mineral resources of southwestern Nigeria. A. A. Elueze (ed.):1-13.

[4] Albanese S, Lavazzo P, Adamo P, Lima A \& De Vivo B (2013) Assessment of the environmental conditions of the Sarno river basin (south Italy): a strem sediment approach. Environmental Geochemistry and Health, 35: 283-297. https://doi.org/10.1007/s10653-012-9483-X..

[5] Awosusi OO \& Adisa AL (2019) Mineralization potential assessment of stream sediment geochemical data using R-mode factor analysis in Nigeria. Journal of Emerging Trends in Engineering and Applied Sciences, 10(2), 54-60.

[6] Bertin C \& Bourg ACM (1995) Trends in the heavy metal content (Cd, Pb, Zn) of river sediments in the drainage basin of smelting activities. Water Research, 29(7), 1729-1736. https://doi.org/10.1016/0043-1354(94)00327-4.

[7] Black R (1980) Precambrian geology of West Africa. Episodes 4:3-8. https://doi.org/10.18814/epiiugs/1980/v3i4/001.

[8] Chakravarty M, Patgiri AD (2009) Metal pollution assessment in sediments of the Dekrong River, NE India. Journal of Human Ecology, 27(1), 6367. https://doi.org/10.1080/09709274.2009.11906193

[9] Forstner U, \& Wittmann G (1983) Metal pollution in the aquatic environment. Berlin, Springer.

[10] Galuszka A \& Migaszewski ZM (2011) Geochemical background - an environmental perspective, Mineralogia, 42 (1), 7-17. https://doi.org/10.2478/v10002-011-0002-y.

[11] Hernandez L, Probst A \& Ulrich E (2003) Heavy metal distribution in some French forest soils: Evidencefor Atmospheric Contamination. The Science of Total Environment.312, 195-210. https://doi.org/10.1016/S0048-9697(03)00223-7.

[12] Kamaruzzaman MC, Ong MS, Noor A, Shahbudin S \& Jalal KCA (2008) Geochemistry of sediment in the major estuarine mangrove forest of Terengganu region, Malaysia. American Journal of Applied Science, 5(12), 1707-1712 (6 pages) https://doi.org/10.3844/ajassp.2008.1707.1712.

[13] Loska K, Wiechula D, Barska B, Cebula E \& Chojnecka A (2003) Assessment of arsenic enrichment of cultivated soils in southern Poland. Polish Journal of Environmental Studies, 12(2), 187-192.

[14] Muller G (1981) The heavy metal pollution of the sediments of Neckars and its tributary. A stocktaking. Chem. Zenith., 105: 157-164.

[15] Nyangababo JT, Henry E \& Omutange E (2005) Lead, cadmium, copper, manganese and zinc in wetland waters of Victoria Late Basin, East Africa. Bulletin of Environmental Contamination and Toxicology, 74(5), 1003-1010 (8 pages) https://doi.org/10.1007/s00128-005-0679-y.

[16] NGSA 2006. Geological Map of Nigeria. Nigeria Geological Survey Agency.

[17] Nude PM, Foli G \& Yidana SM (2011) Geochemical assessment of impact of mine spoils on the quality of stream sediments within the Obuasi mines environment, Ghana. International Journal of Geosciences, 2, 259 - 266. https://doi.org/10.4236/ijg.2011.23028.

[18] Rabee AM, Al-Fatlawy YF, Abdown AN \& Nameer M (2011) Using Pollution Load Index (PLI) and geoaccumulation index (I-Geo) for the assessment of heavy metals pollution in Tigris river sediment in Baghdad region. Journal of Al-Nahrain University, 14: 106-114. https://doi.org/10.22401/JNUS.14.4.14.

[19] Reimann C \& De Caritat P (2005) Distinguishing between natural and anthropogenic sources for elements in the environment: regional geochemical surveys versus enrichment factors. Science of the Total Environment 337, 91 - 107. https://doi.org/10.1016/j.scitotenv.2004.06.011

[20] Rollinson HR (1993) Using geochemical data: Evaluation, presentation, interpretation. Pearson Education Limited, Essex, England

[21] Sakan S, Devic G, Relic D, Andelkovic I, Sakan N \& Dordevic D (2014) Evaluation of sediment contamination with heavy metals: the importance of determining appropriate background content and suitable element for normalization, Environmental Geochemistry and Health. https://doi.org/10.1007/s10653-014-9633-4.

[22] Seshan BRR, Natesan U \& Deepthi K (2010) Geochemical and statistical approach for evaluation of heavy metal pollution in core sediments in southeast coast of Indian. International Journal of Environmental Science and Technology, 7(2), 291-306 (16 pages) https://doi.org/10.1007/BF03326139.

[23] Singh M, Ansari AA, Muller G \& Singh IB (1997) Heavy metals in freshly deposited sediments of the Gomati river (a tributary of the Ganga river): Effects of human activities. Environmental Geology, 29, 246-252. https://doi.org/10.1007/s002540050123.

[24] Soares HM, Boaventura RAR \& Esteves da Silva J (1999) Sediments as monitors of heavy metal contamination in the Ave River Basin (Portugal): Multivariate Analysis of Data. Environmental Pollution, Vol. 105, p. 311 - 323. https://doi.org/10.1016/S0269-7491(99)00048-2.

[25] Sutherland RA (2000) Bed sediment associated trace metals in an urban stream Oahu. Hawaii Environmental Geology, 39(6), 611-627 (17 pages). https://doi.org/10.1007/s002540050473.

[26] Tomilson DC, Wilson DJ, Harris CR \& Jeffery DW (1980) Problems in assessment of heavy metals in estuarine and the formation of pollution index. Helgoland Wiss. MeeresunIter 33(1-4), 566-575(10 pages) https://doi.org/10.1007/BF02414780.

[27] Turekian KK \& Wedepohl KH (1961) Distribution of the elements in some major units of the earth's crust. Geological Society of America Bulletin, 72(2), 175-192.(13pages) https://doi.org/10.1130/0016-7606(1961)72[175:DOTEIS]2.0.CO;2.

[28] USEPA.1999. "US Environmental Protection Agency: Screening level ecological risk assessment protocol for hazardous waste combustion facilities," Appendix E: Toxicity Reference Values, vol. 3.

[29] Zhang J \& Liu CL (2002) Riverine composition and estuarine geochemistry of particulate metals in China - Weathering features, anthropogenic impact and chemical fluxes. Estuarine, Coastal and. Shelf Science, 54: 1051 - 1070. https://doi.org/10.1006/ecss.2001.0879. 